\title{
Who Ya Gonna Call? Confusion Reigns After the Supreme Court's Failure to Define Testimonial and Analyst in Melendez-Diaz v. Massachusetts"
}

\section{INTRODUCTION}

A narcotics detective takes the stand in a drug case. He testifies that the substance the defendant had in his possession is consistent with heroin. The defense attorney cross-examines the detective and discovers that the substance was never tested. The prosecutor's response: a motion to field test the substance in front of the jury. The judge grants the motion. The detective pulls a test kit from his pocket, testifies that he received two hours of online training on conducting drug tests, performs the test, and announces that the substance is in fact consistent with heroin. The jury finds defendant guilty.

This scene unfolded in the Massachusetts case of Commonwealth $v$. Martel after a back-log at the state's laboratory prevented timely testing of the substance in a drug case. ${ }^{1}$ The events in Martel transpired in the wake of United States Supreme Court precedent that may appear to promote the rights of defendants facing incriminating forensic evidence but has instead created chaos concerning the admissibility of such evidence. In Melendez-Diaz v. Massachusetts, the Court reversed the defendant's conviction for a drug offense because the prosecution admitted into evidence a laboratory report that stated the substance he was charged with possessing was cocaine. ${ }^{2}$ The analysts who prepared the report were never called to the stand, giving the defendant no opportunity for cross-examination. ${ }^{3}$ The majority opinion asserts that confrontation of forensic analysts who prepare reports used in criminal

\footnotetext{
* Brooke Edenfield. J.D. candidate 2011, University of Kansas School of Law; B.A. 2004, Washington University in St. Louis. Thank you to Professor Melanie D. Wilson for her helpful suggestions and the Kansas Law Review staff and board for their hard work and assistance. I especially thank my husband Jacob for his love and support.

1. David E. Frank, Fall River District Court Drug Trial Raises Concern: Defense Bar Shocked In-Court Testing Allowed, MASS. LAW. WKLY., Nov. 9, 2009.

2. Melendez-Diaz v. Massachusetts, 129 S. Ct. 2527,2542 (2009).

3. Id. at 2531 .
} 
prosecutions can help defendants uncover incompetence or fraud that may all too often taint forensic evidence. ${ }^{4}$

The Sixth Amendment explicitly gives defendants the right to confront witnesses: "In all criminal prosecutions, the accused shall enjoy the right . . to be confronted with the witnesses against him ...." The Supreme Court has been honing the exact meaning of the Confrontation Clause for over one hundred years. ${ }^{6}$ In 2004, the Court held in Crawford v. Washington that to fully afford defendants the right to "confront" the witnesses against them, all out-of-court statements that are "testimonial" in nature must be barred as hearsay unless the witness is unavailable and the party against whom the testimony is offered had an opportunity for cross-examination either before or during the trial. ${ }^{7}$ Though its rule is triggered only when evidentiary statements are "testimonial," the Crawford Court said: "We leave for another day any effort to spell out a comprehensive definition of "testimonial." " Instead, the Court listed a "core class of 'testimonial' statements," which does not include forensic reports.

On June 25, 2009, before fully clarifying the legal meaning of testimonial, the Supreme Court applied the conceptually incomplete term to the admissibility of forensic evidence in Melendez-Diaz. The Court held that when the government introduced a forensic report stating that a tested substance contained cocaine, the report was testimonial. ${ }^{10}$ Thus, the Court concluded, the prosecution should have called the analysts who prepared it to the stand; in failing to do so, the prosecution deprived the defendant of his rights under the Sixth Amendment's Confrontation Clause. $^{11}$

4. Id. at $2536-37$.

5. U.S. CONST. amend. VI.

6. See generally Mattox v. United States, 156 U.S. 237 (1895) (analyzing the Confrontation Clause in the context of deceased witnesses).

7. Crawford v. Washington, 541 U.S. 36, 59 (2004).

8. Id. at 68 (emphasis added).

9. Id. at 51-52 (stating that the "core class" has been recognized to include "ex parte in-court testimony or its functional equivalent - that is, material such as affidavits, custodial examinations, prior testimony that the defendant was unable to cross-examine, or similar pretrial statements that declarants would reasonably expect to be used prosecutorially, extrajudicial statements . . . contained in formalized testimonial materials, such as affidavits, depositions, prior testimony, or confession statements that were made under circumstances which would lead an objective witness reasonably to believe that the statement would be available for use at a later trial (citations omitted)).

10. Melendez-Diaz v. Massachusetts, 129 S. Ct. 2527, 2532 (2009).

11. Id. 
In explaining its decision, rather than settle the residual confusion surrounding the meaning of testimonial after Crawford, ${ }^{12}$ the Court further muddied the waters by failing to define analyst. As a result, the scope of the decision is difficult to discern. Furthermore, a vague footnote in the majority opinion states: "[W]e do not hold, and it is not the case, that anyone whose testimony may be relevant in establishing the chain of custody, authenticity of the sample, or accuracy of the testing device, must appear in person as part of the prosecution's case."13 Thus, the flimsy rule set forth in Melendez-Diaz seems to be that an analyst must take the stand when a testimonial report is admitted into evidence, but exactly who an analyst is or what testimonial means is anybody's guess.

State and lower courts' interpretations of the holding are unsurprisingly narrow, with many finding testimonial reports to encompass a narrow range of documents. ${ }^{14}$ Furthermore, lower courts tend not to dwell on exactly who constitutes an analyst, often allowing individuals other than those who actually prepare reports to be called to the witness stand. ${ }^{15}$ The result is that modern Confrontation Clause jurisprudence has not changed much in the wake of Melendez-Diaz, which was initially thought to be a landmark case. ${ }^{16}$ When the outcome of a case depends on the accuracy of forensic evidence, it seems that the confrontation rights of today's defendants are no more protected than they were before the Court decided this "landmark" case.

This Note argues that the Supreme Court's decision in MelendezDiaz is correct in that defendants should be able to confront the individuals who prepare the forensic reports used against them in criminal prosecutions. However, the Supreme Court's failure to define

12. See John H. Blume \& Emily C. Paavola, Crime Labs and Prison Guards: A Comment on Melendez-Diaz and Its Potential Impact on Capital Sentencing Proceedings, 3 Charleston L. REV. 205, 219-20 (2009).

13. Melendez-Diaz, 129 S. Ct. at 2532 n.1.

14. See infra Part III.A.

15. See, e.g., United States v. Darden, 656 F. Supp. 2d 560, 563 (D. Md. 2009) (distinguishing Melendez-Diaz because of testimony of lab supervisor who reviewed raw data found by analysts); People v. Rutterschmidt, 98 Cal. Rptr. 3d 390, 408 (Ct. App. 2009) (distinguishing Melendez-Diaz because expert witness testified as to reliability of report but report was not admitted into evidence), review granted, 220 P.3d 239 (2009); Smith v. State, 28 So. 3d 838, 854 (Fla. 2009) (allowing evaluation of report by supervisor of analysis team); Pendergrass v. State, 913 N.E.2d 703, 707-08 (Ind. 2009) (concluding that reliability of evidence could be tested by cross-examination of expert witness); State v. Mobley, 684 S.E.2d 508, 511 (N.C. Ct. App. 2009) (allowing testimony of expert witness who did a technical review of report).

16. See Tom Jackman, Lawmakers Intervene in DUI Issue: Emergency Bill Intended to Ease Burden on State Analysts, WASH. POST, Aug. 20, 2009, at B08 (calling Melendez-Diaz a landmark case). 
analyst and refine its meaning of testimonial, all while leaving a convenient loophole to exclude admittedly relevant testimony, causes lower courts to circumvent the logic that lies at the heart of MelendezDiaz.

First, this Note will demonstrate that the Crawford Court's choice to postpone defining testimonial led to disparities among types of forensic evidence. Many courts distinguish cases to deem entire classes of forensic evidence, such as breathalyzer calibration reports and autopsy reports, nontestimonial. ${ }^{17}$ This allows prosecutors to avoid calling forensic analysts to testify. ${ }^{18}$ Second, courts frequently allow individuals other than those who prepare evidentiary laboratory reports to testify against defendants, ${ }^{19}$ often justifying the procedure by citing the Melendez-Diaz majority's first footnote. ${ }^{20}$ This Note concludes that, to uphold the Confrontation Clause, the Supreme Court should revisit the issue to solidify its definition of testimonial. The Court should also define analyst as the individual who prepares a forensic report, requiring that individual to appear in court to testify every time such a report is used against a defendant in a criminal prosecution.

\section{BACKGROUND}

\section{A. Earlier Confrontation Clause Jurisprudence Valued Face-to-Face Confrontation and Reliability of Evidence}

The Supreme Court first considered the Confrontation Clause in an 1895 case, Mattox v. United States. ${ }^{21}$ There, the Court noted that a defendant gains an advantage by seeing his accuser "face to face, and [by] subjecting him to the ordeal of a cross-examination."22 Another major Confrontation Clause development focused less on face-to-face confrontation. ${ }^{23}$ In Ohio v. Roberts, the Court ruled that Confrontation Clause requirements are met when evidence contains sufficient "indicia

17. See, e.g., State v. Bergin, 217 P.3d 1087, 1090 (Or. Ct. App. 2009) (holding that breathalyzer calibration records are nontestimonial); Wood v. State, 299 S.W.3d 200, 209-10 (Tex. Ct. App. 2009) (holding that autopsy reports are nontestimonial when an autopsy is conducted in the presence of a police officer).

18. Bergin, 217 P.3d at 1088; Wood, 299 S.W.3d at 207.

19. See cases cited supra note 15.

20. See, e.g., Carolina v. State, 690 S.E.2d 435, 436 (Ga. Ct. App. 2010).

21. 156 U.S. 237 (1895).

22. Id. at 244

23. See Ohio v. Roberts, 448 U.S. 56 (1980), abrogated by Crawford v. Washington, 541 U.S. 36 (2004). 
of reliability." "24 Such reliability is demonstrated when evidence is backed by "a showing of particularized guarantees of trustworthiness." 25 This holding seemed to favor the perceived "reliability" of evidence while minimizing the value that the Court historically placed on face-toface confrontation. ${ }^{26}$

\section{B. Crawford v. Washington and Davis v. Washington Demand Live Testimony}

The Court seemed to renew its old appreciation for face-to-face confrontation a quarter-century later in Crawford $v$. Washington. ${ }^{27}$ The petitioner, Crawford, was charged with stabbing a man in the presence of Crawford's wife, Sylvia. ${ }^{28}$ Crawford claimed self-defense and the government sought to admit an audio recording of Sylvia's conversation with police because her account of the events refuted her husband's selfdefense claim. ${ }^{29}$ The Court reasoned that admission of the tape was erroneous because the Confrontation Clause "applies to 'witnesses' against the accused - in other words, those who "bear testimony.","30 Sylvia, the Court reasoned, bore testimony because she made "“[a] solemn declaration or affirmation made for the purpose of establishing or proving some fact." 31 Because Sylvia admitted that she did not observe the victim with a weapon, the fact her declaration proved was that her husband did not act in self-defense. ${ }^{32}$

Crawford's ultimate ruling was that "[t] estimonial statements of witnesses absent from trial [may be] admitted only where the declarant is unavailable, and only where the defendant has had a prior opportunity to cross-examine." 33 Despite the importance of the word testimonial, the Court decided not to generate a "comprehensive definition of

\footnotetext{
24. Id. at 66 (quoting Mancusi v. Stubbs, 408 U.S. 204, 213 (1972)).

25. $I d$.

26. See John G. Douglass, Confronting the Reluctant Accomplice, 101 COLUM. L. REv. 1797, 1801 n.10 (2001)

27. 541 U.S. at 33

28. Id. at 38 .

29. Id. at 39-40.

30. Id. at 51 (quoting $2 \mathrm{~N}$. Webster, AN AMERICAN DiCTIONARY OF THE ENGLiSH LANGUAGE (1828)).

31. Id. (quoting WEBSTER, supra note 30).

32. Id. at $39-40$.

33. Id. at 59 .
} 
"testimonial.",34 Instead, it merely listed the aforementioned "core class of 'testimonial' statements," 35 which did not include forensic reports.

The Supreme Court attempted to clarify the meaning of testimonial two years later in Davis v. Washington. ${ }^{36}$ There, it held that testimonial statements are those that "do precisely what a witness does on direct examination." 37 This attempt at clarification helps little when it comes to forensic reports, however, even if a court finds a forensic report unquestionably testimonial under the Davis standard. The question then becomes, under Melendez-Diaz, who is the "witness" who must testify regarding the validity of the report?

\section{Melendez-Diaz v. Massachusetts Addresses the Admissibility of \\ Forensic Reports}

Melendez-Diaz began as a simple, "garden-variety" drug case with no particularly unique qualities. ${ }^{38}$ The facts are fairly simple. In 2001, police acted on a tip of suspicious activity in a K-Mart parking lot. ${ }^{39}$ An employee frequently received phone calls shortly before a blue sedan picked him up, and then the same car would return him to work. ${ }^{40}$ As the tip predicted, police saw the employee get into a blue sedan, and it returned a short time later. ${ }^{41}$ The officers searched the employee and found "a substance resembling cocaine." 42 Two other men in the car were arrested, including Luis Melendez-Diaz. ${ }^{43}$ On the way to the station, the officers noticed the men fidgeting in the patrol car and later found bags of a white substance hidden in the back seat. ${ }^{44}$ MelendezDiaz stood trial on charges of trafficking and distributing cocaine. ${ }^{45}$ At trial, the court admitted the bags of what appeared to be cocaine accompanied by certificates of analysis stating: "“The substance was found to contain: Cocaine." "46 The person who conducted the drug test

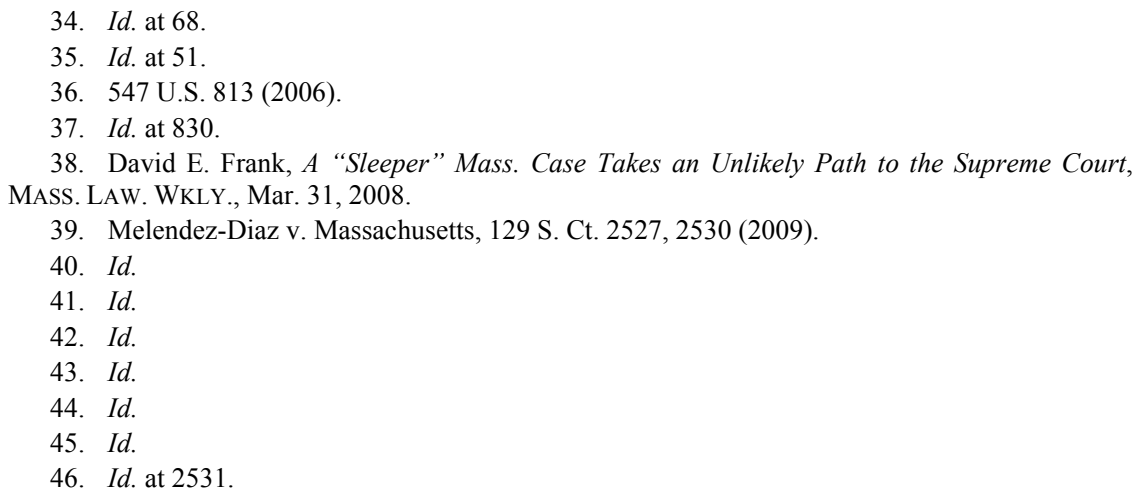


did not appear to testify, ${ }^{47}$ and Melendez-Diaz argued that the certificates were inadmissible because Crawford $v$. Washington mandates in-person testimony by the forensic analyst who attests to forensic reports. ${ }^{48}$

The court allowed the admission of the reports without the analyst's testimony, and Melendez-Diaz was found guilty. ${ }^{49}$ He appealed, arguing that the admission of the certificates violated his Sixth Amendment confrontation rights. ${ }^{50}$ The Appeals Court of Massachusetts affirmed the district court's ruling. ${ }^{51}$ The Supreme Court granted certiorari ${ }^{52}$ and reversed the judgment, ${ }^{53}$ concluding that the certificates were part of the "core class of testimonial statements", 54 that requires in-court testimony under the Court's holding in Crawford v. Washington. ${ }^{55}$

In the majority opinion, Justice Scalia insisted that the Court straightforwardly apply Crawford to conclude that forensic science reports are testimonial documents and the analyst who prepared them must be available for in-court confrontation under the Sixth Amendment's directive. ${ }^{56}$ The majority assured prosecutors that Melendez-Diaz does not require everyone who had a hand in the final preparation of the forensic report to testify: "[W]e do not hold ... that anyone whose testimony may be relevant in establishing the chain of custody, authenticity of the sample, or accuracy of the testing device, must appear in person ...."57 This footnote is frequently cited in the opinions of lower courts to justify an absence of analyst testimony. ${ }^{58}$ The Supreme Court should clarify this footnote so that lower courts may not use it to skirt Melendez-Diaz's apparent requirement that analysts must testify, especially in light of current problems with forensic evidence.

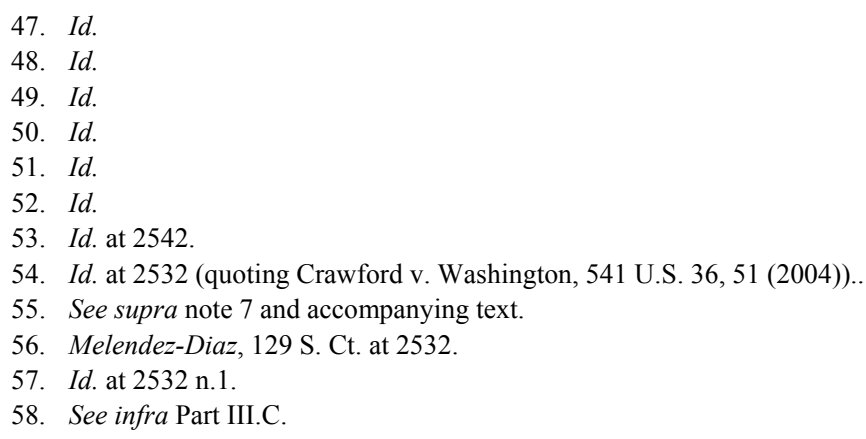




\section{Credibility Problems Exist with Forensic Evidence}

Forensic evidence is an essential tool used in criminal trials to separate the guilty from the innocent. ${ }^{59}$ To accomplish this, of course, "[o]ur criminal justice system ... must rest on facts." 60 While forensic evidence can bring facts to light, the current system suffers from a lack of standardization, which was recently analyzed in the National Academy of Science's (NAS) in-depth report on the current state of forensic evidence. ${ }^{61}$

The Melendez-Diaz majority opinion repeatedly cited the NAS report, which is hailed as "one of the most important developments in forensic science since the creation of the first crime laboratory in this country." 62 The report "raises the worrisome prospect that the quality of evidence presented in court... can vary unpredictably according to jurisdiction." ${ }^{\text {63 }}$ Promoting reliability of forensic evidence and consistency among jurisdictions, therefore, appears essential. The report concludes that forensic science in the United States needs significant improvement. $^{64}$ Thus, courts must equip themselves to properly admit forensic evidence because, in the future, technology will play an increasingly larger role in criminal trials. ${ }^{65}$ Unfortunately, MelendezDiaz, rather than becoming a tool to curb inconsistencies among laboratories, is creating a slew of inconsistencies in the courtroom.

59. Strengthening Forensic Science in the United States: Hearing Before the S. Comm. on the Judiciary, 111th Cong. (2009) [hereinafter Hearing] (statement of Sen. Patrick Leahy, Chairman, S. Comm. on the Judiciary), http://judiciary.senate.gov/hearings/testimony.cfm?id=4038\&wit_id=2629 (last visited Sept. 15, 2010).

60. Id.

61. Comm. on Identifying the Needs of the Forensic Scis., Nat'L Res. Council, StREngthening Forensic SCIENCE IN the United States: A PATH ForWARD 6 (2009) [hereinafter NAT'L RES. COUNCIL].

62. Hearing, supra note 59, at 2 (statement of Prof. Paul C. Giannelli), http://judiciary.senate.gov/pdf/09-09-09\%20Giannelli\%20testimony.pdf.

63. NAT'L RES. COUNCIL, supra note 61 , at 16 .

64. See id.; see also Melendez-Diaz v. Massachusetts, 129 S. Ct. 2527, 2537 (2009) (citing the "serious problems" noted in the report).

65. See, e.g., Dina Temple-Raston, FBI's New Technology Revolutionizes DNA Analysis, NPR (Jan. 28, 2008), http://www.npr.org/templates/story/story.php?storyId=18435256 (explaining how a new robotic device called a mass spectrometer will "open up all new kinds of evidence and all new kinds of cases" in the area of DNA analysis). 
2. Justice Scalia's Majority Opinion Fails to Spell Out a Workable Cure for the Problems Reported by the NAS Report

Justice Scalia, writing for the majority, cited a portion of the NAS report stating that " " $\mathrm{t}] \mathrm{he}$ forensic science system...has serious problems that can only be addressed by a national commitment to overhaul the current structure." 66 He concluded that cross-examination will allow defendants to showcase "an analyst's lack of proper training or deficiency in judgment." 67

At first blush, it appears that the Court intended the Melendez-Diaz holding to be quite broad, designed to help cure current deficiencies in forensic evidence. But according to Justice Scalia, the decision merely settles the question of whether the reports identifying the white substance as cocaine were testimonial and is a straightforward application of Crawford. ${ }^{68}$ The majority explained that the certificates were created " under circumstances which would lead an objective witness reasonably to believe that the statement would be available for use at a later trial,", since the analysts were aware that the very reason the certificates were created was for use as evidence in a criminal case. ${ }^{69}$ Therefore, he concluded, the certificates were testimonial under Crawford. ${ }^{70}$

While the Court's use of a "reasonable belief" standard necessarily invites judicial interpretation and discretion, a comprehensive definition of what constitutes a testimonial forensic report would, in contrast, tell lower courts exactly when an analyst must testify. Thus, by deeming the statements testimonial, the majority created an expansive gray area for judges who must decide whether a specific forensic report is testimonial, and, in turn, whether the analyst who created it must be called as a witness.

The majority stressed that the procedural goal of the Confrontation Clause is to assess the reliability of evidence. ${ }^{71}$ Reliability is exceptionally important in the field of forensic testing, which is arguably neither neutral nor reliable in its current state. ${ }^{72}$ The Court argued that its holding would increase reliability, at least when it comes to analysts who lie or exaggerate, and that "[c]onfrontation is one means of assuring

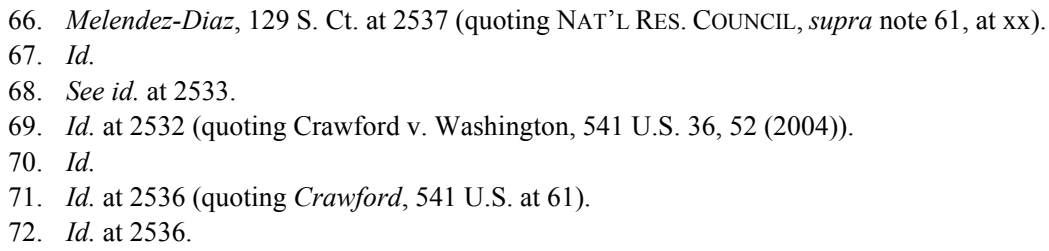


accurate forensic analysis. ... [O]f course, the prospect of confrontation will deter fraudulent analysis in the first place."73 The majority accurately pointed out that had the prosecution called the individuals who prepared the drug certificate to testify, the defendant in MelendezDiaz could have discovered the method the analysts used to reach their conclusion through cross-examination. ${ }^{74}$ But because the Court failed to define analyst, even in a post-Melendez-Diaz world, many defendants do not have access to the person best able to attest to the reliability of forensic evidence admitted into evidence. ${ }^{75}$ While the Court promoted the ideal of evidentiary reliability, ${ }^{76}$ it could have better served this goal by clearly defining a procedure lower courts must follow.

3. Justice Kennedy's Dissent Predicts the Impact of the Majority's

Failure to Define Testimonial and Analyst

In his dissent, Justice Kennedy pointed out that the majority incorrectly based its ruling on Crawford and Davis because neither case mentioned forensic analysis. ${ }^{77}$ These cases present confrontation issues concerning witnesses who were present at the time of the crimes alleged, ${ }^{78}$ while forensic scientists are generally not present during a crime's commission.

Furthermore, in Crawford and Davis, the statements at issue concerned events that occurred in the past. Forensic analysts, on the other hand, prepare their reports nearly contemporaneously with the observation of test results. ${ }^{79}$ Finally, the testimonial statements at issue in those cases were given in response to interrogation, completely unlike forensic reports. ${ }^{80}$ Justice Kennedy argued that this means the majority's cited precedents were readily distinguishable from Melendez-Diaz, ${ }^{81}$ thus isolating a fundamental flaw in the majority's reasoning - old standards are not readily applicable to forensic evidence and analysts, which do not fit neatly into traditional concepts of evidence and witnesses.

Even if the majority opinion was properly rooted in precedent, the dissent showed that the ruling was written in a manner that makes it

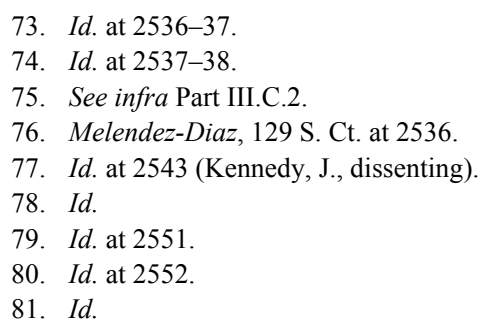


difficult to apply practically. One problem is Justice Scalia's relentless reliance on the phrase "testimonial statements," despite failing to explain exactly what testimonial means. Notably, Justice Kennedy asserted that the Court only used the term testimonial in Crawford and Davis because "the adjective ... avoid[ed] the awkward phrasing required by reusing the noun "witness." 82 Rather than attempt to clarify testimonial himself, Justice Kennedy suggested that the term is not as important as the majority seemed to believe, analogizing modern-day analysts to constitutional-era copyists, whose affidavits were admitted into evidence without a confrontation requirement. ${ }^{83}$ In other words, the dissent seemed to think that the majority's exaltation of testimonial evidence was a bit misplaced. While this theory ignores the starring role that the term testimonial played in pre-Melendez-Diaz confrontation cases, such as Crawford, it makes for an interesting observation-without specifying exactly what the definition of testimonial is for scientific evidence, the majority opinion left so much room for interpretation that lower courts can treat the work of forensic analysts as casually as that of glorified copyists.

The dissent next criticized the majority's failure to define analyst. ${ }^{84}$ Justice Kennedy predicted that some jurisdictions would require each of the many individuals involved in preparing a forensic report-each analyst - to testify in court. ${ }^{85}$ The impact of such a requirement would be that if even one of these people is unavailable, "the Court has, for all practical purposes, forbidden the use of scientific tests in criminal trials." 86 Justice Kennedy unapologetically pointed out the majority opinion's leaps in logic regarding the terms testimonial and analyst. His "slippery slope" critique, while perhaps far-fetched, nonetheless emphasized that because the majority failed to fully define and limit the scope of its decision, substantial problems were bound to arise.

Unfortunately, many post-Melendez-Diaz decisions legitimize Justice Kennedy's prediction; the majority opinion provided states and lower federal courts insufficient guidance to decide when forensic reports are admissible in court without live testimony. ${ }^{87}$ The result is that confrontation rights are not sufficiently protected in the modern scientific era.

82. Id.

83. Id. at $2552-53$.

84. Id. at $2544-47$.

85. See id. at $2545-46$.

86. Id. at 2544 .

87. See infra Part III. 


\section{ANALYSIS}

\section{A. Courts Deem Many Categories of Forensic Reports Nontestimonial}

Melendez-Diaz's incomplete articulation of testimonial gives courts great leeway to decide that various types of forensic evidence do not fall under the scope of the Court's holding. Therefore, many defendants do not have the opportunity to confront the analyst who reported evidence via cross-examination. Interestingly, soon after the Supreme Court decided Melendez-Diaz, courts immediately began to distinguish several categories of reports from other testimonial documents. ${ }^{88}$ Courts have now generally converged, and when dealing with many different types of evidence, the original analyst usually need not testify. ${ }^{89}$ The reporting analyst is so seldom required to testify, in fact, that it seems courts are taking liberties with Melendez-Diaz's confusing language to justify admitting evidence in a convenient manner, rather than in the way that will best protect defendants' constitutional rights.

Among the reports declared by state and lower courts to be nontestimonial are military drug test results, ${ }^{90}$ certificates of accuracy for speed radar devices, ${ }^{91}$ and records for breathalyzer machines. ${ }^{92}$ Some courts even find defendants' requests to examine reports related to the functionality of breathalyzer machines to be so overly broad and burdensome that such reports are not discoverable. ${ }^{93}$

Courts' justifications for finding reports nontestimonial vary. For example, the Illinois Court of Appeals determined that autopsy reports are nontestimonial because they are business records and do not prove an element of the offense at issue. ${ }^{94}$ The Indiana Court of Appeals took a different approach, finding the certificate of accuracy for a breath-testing machine in a DUI case nontestimonial because it was not prepared for a single defendant and was not a formal affidavit. ${ }^{95}$ The California

88. See cases cited supra note 15 .

89. See supra note 15 and accompanying text.

90. United States v. Skrede, 2009 WL 4250031, at*7 (A.F. Ct. Crim. App. Nov. 23, 2009) (explaining that military drug test results are nontestimonial business records).

91. United States v. Forstell, 656 F. Supp. 2d 578, 580-81 (E.D. Va. 2009).

92. State v. Bergin, 217 P.3d 1087, 1089-90 (Or. Ct. App. 2009).

93. See State v. McCurdy, No. 0909016626, 2010 WL 546499, at*3 (Del. Ct. Com. Pl. Feb. 3, 2010) (request for calibration records overbroad and burdensome to the State); State v. Tindell, No. E2008-02635-CCA-R3-CD, 2010 WL 2516875, at *15-18 (Tenn. Crim. App. June 22, 2010) (source code for breathalyzer device not discoverable).

94. People v. Cortez, 931 N.E.2d 751, 756-57 (Ill. App. Ct. 2010).

95. Ramirez v. State, 928 N.E.2d 214, 220 (Ind. Ct. App. 2010). 
Supreme Court rationalized in People v. Geier that a DNA report is nontestimonial by a process of elimination: "[A] statement is testimonial if (1) it is made to a law enforcement officer or by or to a law enforcement agent and (2) describes a past fact related to criminal activity for (3) possible use at a later trial. Conversely, a statement that does not meet all three criteria is not testimonial." ${ }^{96}$

With various avenues to declare reports nontestimonial available to courts, the scope of Melendez-Diaz is, in practice, extraordinarily narrow. If the Supreme Court's motive is truly to give defendants the opportunity to cross-examine analysts to unveil "an analyst's lack of proper training or deficiency in judgment,"97 Melendez-Diaz's lackluster requirements fail to empower defendants as intended.

\section{B. Melendez-Diaz's Failure to Define Analyst Prompts Courts to Admit Results of Forensic Reports Without Accompanying Testimony of the Author}

Even when courts recognize reports as testimonial, which would seem to require the author's appearance per Melendez-Diaz's holding, numerous states allow individuals other than those who actually perform forensic reports to take the stand. ${ }^{98}$ Thus, contrary to Justice Scalia's promise that defendants can cross-examine analysts to bring to light a lack of knowledge or to uncover a poor decision, ${ }^{99}$ few post-MelendezDiaz defendants have a meaningful opportunity to do so.

In Pendergrass $v$. Indiana, the Indiana Supreme Court was one of the earlier courts to hold that the expert testimony of a supervisor may replace the testimony of the person who created a report. ${ }^{100}$ The court admitted testimony of a laboratory supervisor regarding the DNA

96. People v. Geier, 161 P.3d 104, 138-39 (Cal. 2007). Notably, "[t]he California Supreme Court has recently granted review in four cases involving this issue, some of which concluded that Geier had been impliedly overruled, and some concluding it was still good law." People v. Velazquez, No. E044109, 2009 WL 5062027, at*6 (Cal. Ct. App. Dec. 24, 2009). See People v. Rutterschmidt, 98 Cal. Rptr. 3d 390 (Ct. App. 2009), review granted, 220 P.3d 239 (2009); People v. Gutierrez, 99 Cal. Rptr. 3d 369 (Ct. App. 2009), review granted, 220 P.3d 239 (2009); People v. Dungo, 98 Cal. Rptr. 3d 702 (Ct. App. 2009), review granted, 220 P.3d 240 (2009); People v. Lopez, 98 Cal. Rptr. 3d 825 (Ct. App. 2009), review granted, 220 P.3d 240 (2009).

97. Melendez-Diaz v. Massachusetts, 129 S. Ct. 2527, 2537 (2009).

98. See cases cited supra note 15 .

99. Melendez-Diaz, 129 S. Ct. at 2537.

100. See generally 913 N.E.2d 703 (2009) (holding that admission of a certificate of analysis pertaining to DNA evidence with expert testimony but without testimony of the laboratory processor did not violate defendant's Sixth Amendment right of confrontation). 
analyses conducted by her employee instead of the employee herself. ${ }^{101}$ The court reached its decision because " $[\mathrm{t}]$ he laboratory supervisor who took the stand did have a direct part in the process by personally checking [the employee's] test results," meaning that the supervisor was able to verify the tests' accuracy, the standards followed in the lab, and whether the analyst followed those standards. ${ }^{102}$

However, questioning a laboratory supervisor will probably not yield as much information as calling the person who actually conducted the tests to testify. In Pendergrass, defense counsel asked the supervisor which of two tests were conducted first. ${ }^{103}$ She responded, "II don't have any knowledge of that." "104 When asked whether "anything indicated a difficulty in creating the DNA profile," 105 she had to review the tester's notes, which were not admitted into evidence. ${ }^{106}$

The supervisor's testimony allowed for potentially unreliable evidence in three ways: (1) the supervisor was unfamiliar with the exact testing procedure, (2) she was unaware of whether the analyst encountered problems, and (3) the notes she reviewed were not admitted into evidence. Thus, the Pendergrass court set a bad precedent by admitting less-than-reliable evidence. First, that the supervisor was unfamiliar with the order in which the tests were performed calls into question the accuracy of the court's assertion that she was familiar enough with the standard operating procedures in the laboratory to tell whether the analyst deviated from those procedures. ${ }^{107}$ Second, had the supervisor been aware of a specific problem with the report, the defense attorney could have been put on notice of a potential error and explored that topic further. Presumably, the analyst herself would have been better able to assist the defendant in obtaining this information than her supervisor. Finally, because the notes upon which the supervisor based her opinions were not admitted into evidence, the defendant and factfinder were deprived of the opportunity to compare the supervisor's interpretation of the notes with the notes themselves. The supervisor may have misread or misunderstood the notes, while the analyst herself would have been better able to explain exactly what happened during the tests.

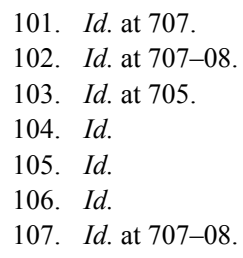


Other courts allow laboratory supervisors to testify in the actual analyst's stead. In State v. Dilboy, the New Hampshire Supreme Court sanctioned this method by taking a particularly narrow view of the Melendez-Diaz rule, stating that it addresses only a very " "narrow category of testimonial statements,", which is limited to "“ex parte outof-court affidavits of laboratory analysts regarding ... drug tests." "108 In Dilboy, the defendant challenged the court's decision to allow testimony of a laboratory supervisor-who testified that various drugs, including cocaine, were found in Dilboy's blood and urine-because the supervisor did not perform the tests. ${ }^{109}$ In allowing the supervisor's testimony, the court noted Melendez-Diaz's oft-quoted disclaimer: "[I]t is not the case[] that anyone whose testimony may be relevant in establishing the chain of custody, authenticity of the sample, or accuracy of the testing device, must appear in person as part of the prosecution's case." $" 110$

Many other courts have held that, under Melendez-Diaz, the Confrontation Clause does not require the analyst who completed a forensic report used against a defendant to appear to testify. ${ }^{111}$ As courts skirt Melendez-Diaz's apparent requirements, the idea that the person who prepared the records should be the same person who is called to the stand has all but vanished. For example, in Haywood v. State, a case involving a drug affidavit very similar to that in Melendez-Diaz, a lab supervisor's testimony was admissible on the grounds that she had reviewed the technician's work for accuracy. ${ }^{112}$

Eliciting testimony from laboratory supervisors is not uncommon, and courts are quick to demonstrate that this practice is consistent-or, at least, not inconsistent-with Melendez-Diaz. For example, the Georgia Court of Appeals reasoned, "Melendez-Diaz specifically did not decide ... whether the technician or chemist who actually performed the tests must testify at trial." "113 To justify its conclusion, the court cited Justice Scalia's famous footnote promising that it is not necessary for anyone possessing relevant information regarding forensic reports to testify. ${ }^{114}$

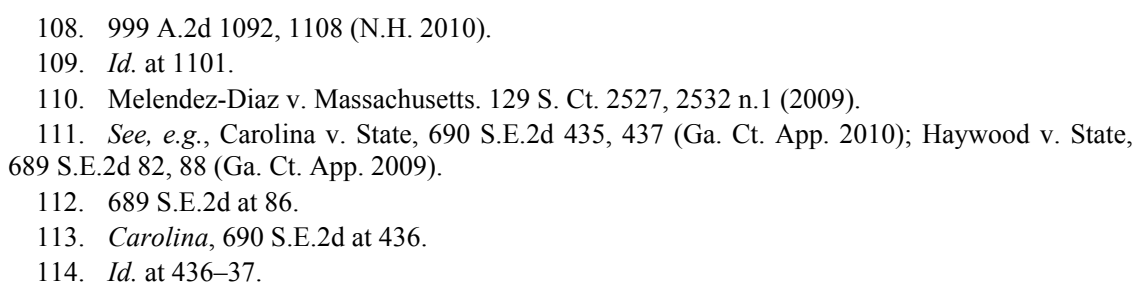




\section{Analysts Should Be Required to Appear in Court to Testify Every Time Forensic Documents Are Used Against Criminal Defendants}

1. Melendez-Diaz's Failure to Define Testimonial Diminishes Defendants' Rights

Defendants should have the unequivocal right to confront witnesses who present scientific evidence against them in criminal cases, but the majority diminished this right with its faulty reasoning. Its use of poorly defined terms gives lower courts too much leeway when deciding how far the Confrontation Clause extends. As stated above, Justice Kennedy's fear that the majority gives states little guidance in implementing the new standard ${ }^{115}$ has indeed materialized. Courts seem to dodge the burden of requiring in-court testimony whenever possible.

On the other hand, some courts properly apply Melendez-Diaz and require analysts to appear to attest to forensic records. ${ }^{116}$ The rationale such courts employ is that "the United States Supreme Court has explicitly ruled that admission of such certificates without testimony from the authoring analyst violates the Sixth Amendment right to confrontation" "117 or that, in the wake of Melendez-Diaz, "a defendant's Sixth Amendment right is violated when the defendant is not allowed to confront the person who created the lab report used at his trial." 118 Note that these courts are not interpreting Melendez-Diaz to mean that defendants have a Sixth Amendment right to merely confront someone but, very specifically, to confront analysts who prepare evidence against them. If Melendez-Diaz left room for substitute analysts' testimony, the Court should have specified how far attenuated the testifying analyst may be from the person who actually created the report. Better, the Court should have firmly ruled that there can be no substitutions.

\section{Analysts Are Not Interchangeable}

Even when documents are declared testimonial, almost universally, state and lower courts allow the testimony of experts in place of analysts'

115. Melendez-Diaz, 129 S. Ct. at 2544 (Kennedy, J., dissenting).

116. See, e.g., Koenig v. State, 916 N.E.2d 200, 201 (Ind. Ct. App. 2009) (applying MelendezDiaz to require live testimony to accompany admission of blood test certificates); Commonwealth v. Chery, 915 N.E.2d 284, 285-86 (Mass. App. Ct. 2009) (same regarding a ballistics report); Commonwealth v. DePina, 917 N.E.2d 781, 783 (Mass. App. Ct. 2009) (same regarding drug analysis report)

117. DePina, 917 N.E.2d at 789 (emphasis added).

118. Koenig, 916 N.E.2d at 201 (emphasis added). 
when the substitute analysts (1) draw their own conclusions ${ }^{119}$ and (2) do not merely read from the primary analysts' reports. ${ }^{120}$ These appallingly minimal requirements do nothing to remedy the vast problems documented in the NAS report cited by Justice Scalia. ${ }^{121}$ The Supreme Court should revisit the issue and seal the holes in its logic - particularly in the exceptionally leaky first footnote, which lower and state courts are tapping again and again to justify implementing minimal standards.

The Melendez-Diaz majority claimed that the ruling would enable defendants to test the reliability of analysts' work. ${ }^{122}$ Therefore, courts should not allow an expert or some other individual to testify in lieu of the analyst who actually prepared a report. While expert testimony could allow defendants to confront someone regarding laboratory results and may enable a defense attorney to uncover an error in the report during cross-examination, this possibility will not promote evidentiary reliability to the same extent as confronting the analyst herself. When an analyst lies to make a report appear accurate or makes a mistake during her analysis, an expert who reviews the records may have no way to expose the error. Allowing testimony from substitutes-such as laboratory supervisors, co-workers, or independent experts - sets a dangerous precedent. Even top experts in their fields are not omniscient and cannot tell the fact-finder with full certainty what transpired during the testing period. Maybe the analyst herself can.

On the topic of forensic reports, a Michigan defense attorney aptly noted, "You literally have to look at the science and challenge the science that's out there." 123 This statement was in response to the closure of a Detroit laboratory after error rates on forensic reports were found to be as high as ten percent. ${ }^{124}$ Confrontation, according to the attorney, means that "[t]he technician has to say, 'This is what I did and

119. See, e.g., United States v. Alexander, Nos. 2:04-cr-71, 2:09-cv-294, 2010 WL 404072, at *4 (N.D. Ind. Jan. 25, 2010) (permitting testimony by DEA forensic chemist who formed an expert opinion after reviewing and confirming the results generated by his partner); Rector v. State, 681 S.E.2d 157, 160 (Ga. 2009) (allowing testimony by state's toxicologist that drew independent conclusion from the report of another toxicologist); State v. Lui, 221 P.3d 948, 955-56 (Wash. Ct. App. 2009) (admitting DNA analysis of one analyst via expert testimony of another).

120. See, e.g., State v. Locklear, 681 S.E.2d 293, 305 (N.C. 2009) (holding that testimony was not admissible when expert witness testified using an autopsy report prepared by another doctor who was not shown to be unavailable); State v. Galindo, 683 S.E.2d 785, 788 (N.C. 2009) (holding that a substitute chemist's testimony was not admissible when based solely on the report of another analyst).

121. Melendez-Diaz v. Massachusetts, 129 S. Ct. 2527, 2537 (2009).

122. Id. at 2538 .

123. Carol Lundberg, Show Me the Lab Tech: U.S. Supreme Court Confrontation Clause Decision May Have Some Impact on Michigan After All, MI. LAW. WKLY., July 27, 2009.

124. Id. 
this is how I did it,' and answer questions on it." 125 This is a seemingly simple process.

The Melendez-Diaz majority could have avoided considerably diminishing defendants' rights had it ventured to make such a clear statement. It did not. And lower courts are seizing the opportunity to interpret the rule in the most convenient way possible, even if that means the problems cited in Melendez-Diaz persevere at the least and, at the worst, become substantially more damaging to defendants' rights as forensic evidence is used increasingly in the courtroom. ${ }^{126}$

\section{Ignoring Evidentiary Problems Promotes Evidentiary Unreliability}

Many types of forensic evidence are used in courts on a regular basis, including fingerprints, DNA and other biological evidence, controlled substances, shoe prints and tire tracks, ballistics, hair and fibers, paint and coatings, and document analyses. ${ }^{127}$ As courts determine whether various types of reports are testimonial, the current trend allowing substitute analysts to testify is spreading throughout the entire field of forensic science. ${ }^{128}$ This result is incompatible with Melendez-Diaz's general message that analysts must be available to testify on the accuracy of forensic evidence. ${ }^{129}$

While "science has always been marked by upheaval as it evolves and transforms itself through discovery,"130 scientific breakthroughs come quickly and technology advances at increasingly rapid rates. In contrast, the law has a reputation for resisting change, always a step behind science. ${ }^{131}$ When science and law come together to prove a defendant's guilt through forensic evidence, the law must keep pace with science to ensure the reliability of this evidence. The law does not enjoy the same luxury as science; it cannot afford to endure upheaval.

Melendez-Diaz created upheaval by opening the door to evidentiary unreliability. As demonstrated above, courts tend not to require the person who actually prepared scientific reports to explain the procedures behind those reports and the conclusions the reports contain, permitting

\footnotetext{
125. Id. (internal quotation marks omitted).

126. See supra note 65 and accompanying text.

127. See generally NAT'L RES. COUNCIL, supra note 61, at 127-81 (describing forensic science disciplines).

128. See supra notes 111-14 and accompanying text.

129. Melendez-Diaz v. Massachusetts, 129 S. Ct. 2527, 2532-33 (2009).

130. Kelly M. Pyrek, Forensic Science Under Siege: The Challenges of Forensic LABORATORIES AND THE MEDICO-LEGAL DEATH INVESTIGATION SYSTEM 8 (2007).

131. Id. at 15 .
} 
otherwise inadmissible reports on the theory that confrontation rights are protected when substitute analysts take the stand and testify as to the accuracy of another's work. Even if this person must be certified as an expert or otherwise considered qualified to interpret the report, this individual was not present when the test was conducted. Certainly, however, the solution is not to require every expert to pull a drug test kit out of his pocket - such requirement would make a mockery of a constitutional guarantee. Judicial efficiency may be promoted when analysts can remain in the laboratory instead of being hailed into court, but, as Justice Scalia emphasized, "The Confrontation Clause ... is binding, and we may not disregard it at our convenience." 132

\section{CONCLUSION}

The Supreme Court should revisit the issue of the Confrontation Clause's applicability to forensic evidence, paying close attention to the special evidentiary problems demonstrated in the NAS report. A lack of national standardization makes it extremely important for every piece of forensic evidence to receive close scrutiny. Until those national standards are in place, the Supreme Court must work to ensure that defendants have every opportunity to check the reliability of this type of evidence. The first step is to ensure that the person who created the evidence is available for questioning. Thus, the holding in MelendezDiaz is correct, but the opinion itself is riddled with escape hatches that detract from what the opinion is really about - the right to confrontation. For defendants to fully benefit from Sixth Amendment guarantees, the Supreme Court should clarify what is meant by testimonial. The Crawford Court left this task for "another day." That day should have arrived on June 25, 2009 - the day Melendez-Diaz was decided.

Testimonial documents should include all forensic reports, not just those in affidavit form. And simply replacing the report with the testimony of an analyst who had nothing to do with preparing the report is not a viable solution. The greatest problems left unresolved by the opinion spring from the ambiguous term analyst. In revisiting the issue, the Court should specify that the analyst must be the person who actually completed the forensic report admitted into evidence, not a co-worker, not an "expert," not simply a living, breathing person capable of giving an opinion based on the reports of another. Otherwise, cross- 
156

KANSAS LAW REVIEW

[Vol. 59

examination can only yield partial truths. Defendants are entitled to the whole truth, and nothing but. 